\title{
平成28年台風10号による 仙台海岸海浜変形への影響
}

\author{
三戸部 佑太 1 ・田中 $\quad$ 仁 $^{2}$ ・鈴木 彰容 ${ }^{3}$ ・梅田 信 4 ・ \\ 小森 大輔 5 ・峠 嘉哉 6 \\ 1 正会員 東北学院大学講師 工学部環境建設工学科（干985-8537 宮城県多賀城市中央 1-13-1） \\ E-mail: yuta.mitobe.c5@tohoku.ac.jp \\ 2 フェロー会員 東北大学教授 大学院工学研究科（T980-8579 仙台市青葉区荒巻字青葉 6-6-06） \\ 3 学生会員 東北大学 大学院工学研究科（９980-8579 仙台市青葉区荒巻字青葉 6-6-06） \\ 4 正会員 東北大学准教授 大学院工学研究科（广980-8579 仙台市青葉区荒巻字青葉 6-6-06) \\ 5 正会員 東北大学准教授 大学院環境科学研究科（于980-8579 仙台市青葉区荒巻字青葉 6-6-06） \\ 6 正会員 東北大学助教 大学院工学研究科（干980-8579 仙台市青葉区荒巻字青葉 6-6-06)
}

平成 28 年台風 10 号による高潮・高波の実態調査およびその海浜地形変化への影響を調べるため仙台海 岸において台風通過当日から翌日にかけて現地調査を実施した。 その結果最大で T.P. $4 \mathrm{~m}$ 程度まで波浪が遡 上したことがわかった。また，仙台新港周辺の海岸沿いの盛り土法先に大きな侵食が生じていた，蒲生干 潟の前の砂丘部では越波が生じ，これにより干潟内に砂が輸送されたことがわかった.

空中写真による汀線変化の調査を行い，平均的に 20 30m 程度の汀線後退が生じたことがわかった．岸 沖漂砂により概ね 1 2 か月で台風来襲以前の汀線位置まで回復したが，砂丘部に越波が生じた蒲生干潟や 井戸浦周辺においては汀線の回復が遅い. 河口や離岸堤に加えて 2011 年津波により海岸線に露出された構 造物による沿岸漂砂の捕捉効果によりその漂砂上手側で汀線の回復傾向が大きい.

Key Words : field survey, aerial photographs, shoreline analysis, erosion, recovery process, overtopping

\section{1. はじめに}

平成28年に太平洋側から東北地方一上陸した台風10 号は，主に東北から北海道にかけて多大な被害を及ぼし た. 今次台風の進路は観測史上初めて太平洋側から東北 地方一上陸した台風であり，また東北地方では台風10号 の接近が満潮時と一致していたため高潮や高波による沿 岸部での被害が懸念されていた．実際に沿岸部において も港湾施設の破損や高潮による冠水による通行止めなど 多数の被害が報告されている1).

仙台海岸は2011年東日本大震災津波により生じた大規 模な地形変化の影響が現在も残存しており2), 海岸侵食 などの防災上の問題も発生していることから，海浜変形 に関する継続的な調査が必要とされている領域である. そこで台風来襲当日および翌日に仙台海岸を対象に現地 調査を実施し，今次台風による高潮および高波の実態を 把握するとともに，それによる海浜地形への影響につい て空中写真に基づく汀線変化をもとに議論する.

\section{2. 研究方法}

本研究では名取川河口から仙台新港までの延長約 $12 \mathrm{~km}$ の砂浜海岸（図-1）を対象として 2016 年 8 月 30 日 16 時〜 18 時 (台風通過時) および 2016 年 8 月 31 日 9 時 30 分〜14 時 (台風通過翌日) に現地調査を実施した. なお対象領域の北側に位置する仙台新港において台風通 過時の 8 月 30 日 15 時に最大潮位偏差 $50 \mathrm{~cm}$, 最大有義波 高 $6.44 \mathrm{~m}$ を記録している. 本領域では数十年にわたり約 1 2 か月間隔の高頻度で空中写真が撮影されており, 継 続的に海浜変形に関する調查が実施されてきた. 北向き の沿岸漂砂が卓越することが知られており，本領域中に 流れ出る七北田川の河口部では右岸砂州が大きく発達し ている. 2011 年津波後も継続的に空中写真撮影を実施し ており,その海浜地形への影響について議論されてきた. 仙台海岸においてはそれぞれ七北田川および名取川の河 口左岸側に位置する蒲生干潟および井戸浦周辺で 2011 年津波により大規模な侵食が生じており，これらの領域 が大きく凹んだ汀線形状となることで漂砂過程に影響を 生じており ${ }^{3)}$ ，いまだに従前の汀線位置よりも大きく後 


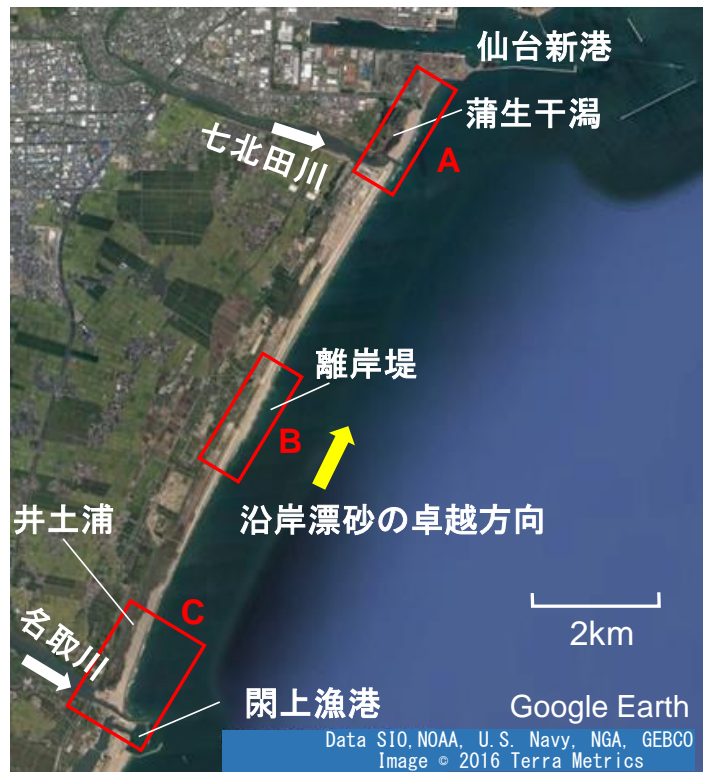

図-1 研究対象領域

退したままの領域が残っている．本研究では台風来襲前 の 2016 年 7 月 12 日および台風来襲後の 9 月 1 日， 10 月 1 日，11月 5 日に撮影された空中写真に基づき今次台風 による汀線変化およびその後の回復過程を示寸とともに, 2011 年津波による影響について議論する.

\section{3. 現地調査結果}

\section{(1) 高潮・高波の様子および痕跡}

図-2 は仙台新港付近（図-1:A）において台風通過時に 撮影した波浪の様子と台風通過翌日の水位痕跡の写真を 示している. 本領域の北端部の仙台新港付近は盛り土に より高台となっているが，台風通過時には高波浪が来襲 し，盛り土法先まで到達していることがわかる（写真 A1・A2)．またこの高台部分から七北田川河口までの間 に位置している蒲生干潟ではその前面の砂丘を越波し, 干潟内に海水が侵入している様子が確認された（写真 A3)。なお，2011 年津波後の復旧工事により建設された 七北田川河口右岸側の堤防（天端高 T.P. 7.2m）にみられ た水位痕跡から約T.P. $2.6 \mathrm{~m}$ 程度まで水位が上昇していた ことがわかった（写真 A4）。

対象領域中央に位置寸る荒浜海岸（図-1:B）において は 6 基の離岸堤が設置されているが，台風通過時にはこ れらを乗り越える高波浪が来襲し，堤防法先付近まで遡 上している様子が確認された (図-3). また周辺において 堤防法先付近に漂着物が堆積している様子も確認された

(写真 B2) . 堤防天端高 (T.P. $7.2 \mathrm{~m}$ ) との比較から T.P. $3.8 \mathrm{~m}$ 程度まで溯上高が達していたと推定される.

名取川河口左岸側（図-1:C）に位置寸る井戸浦の前面 の砂丘部においても高波浪の越波が確認された（図-4）.
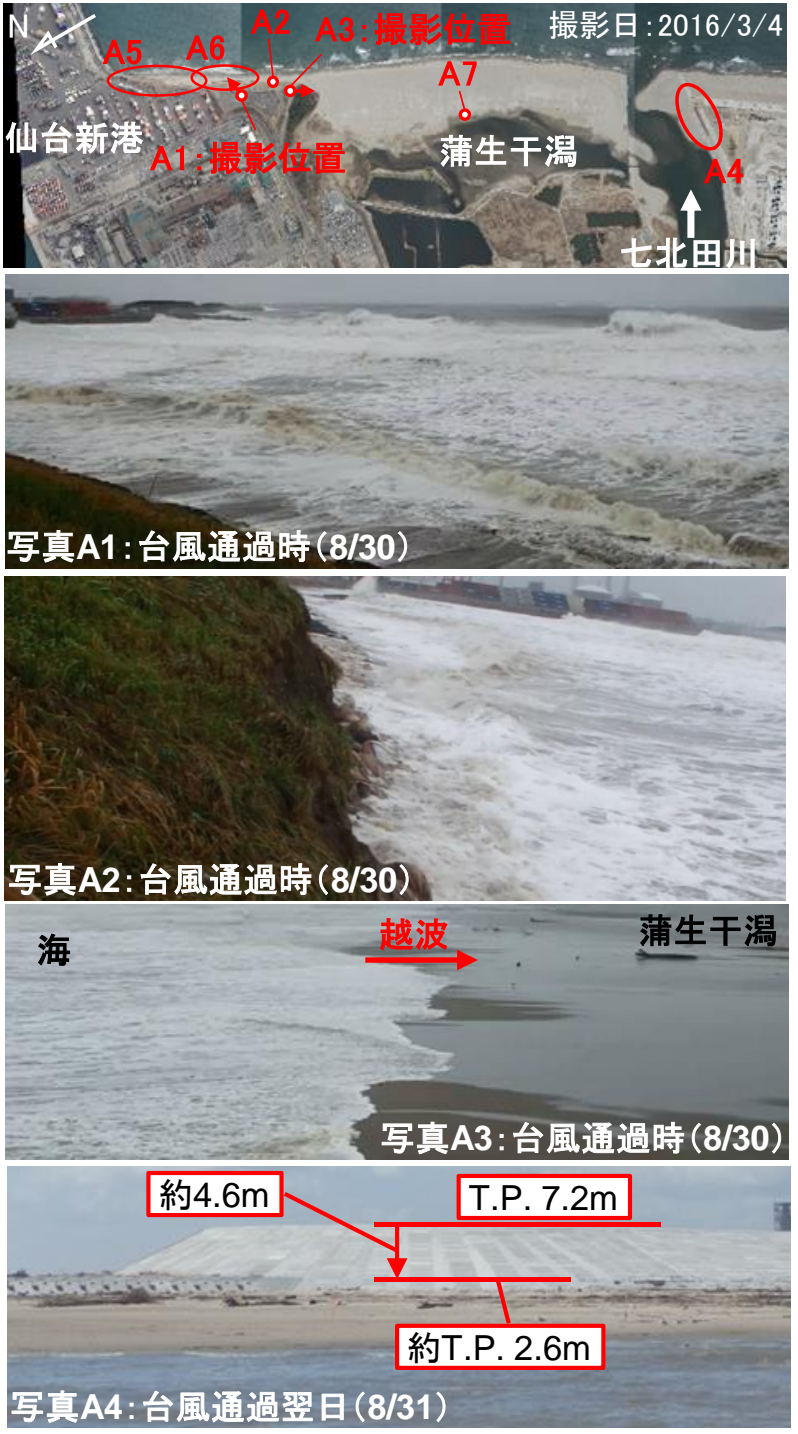

図-2 七北田川河口から仙台新港までの現地調査時の写真. 上図 のA1 A7は対応する写真の撮影位置（A5 A7 : 図-5）

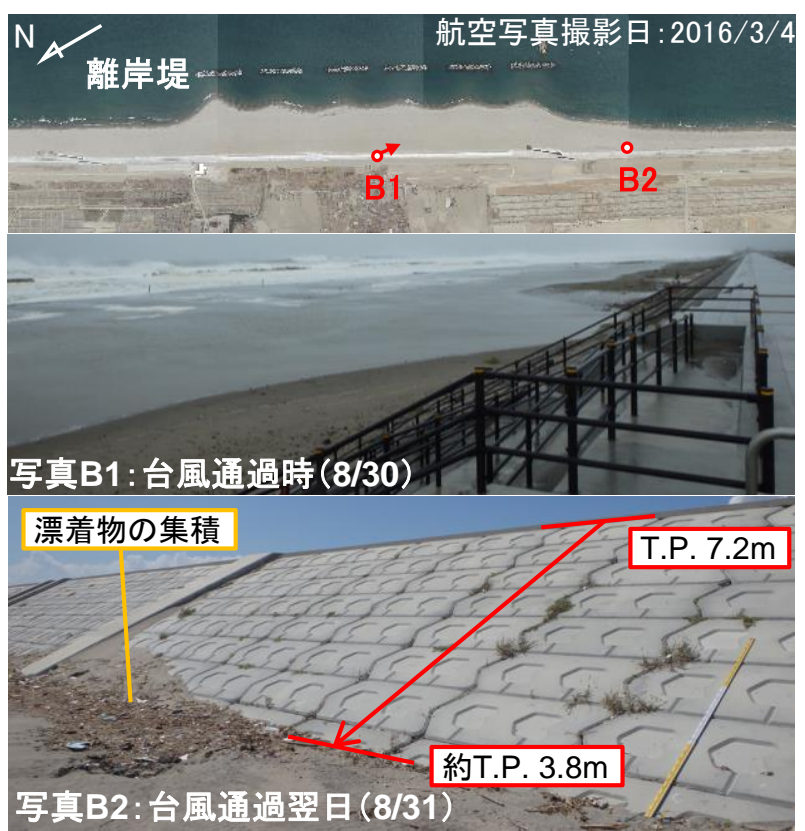

図-3 荒浜海岸における現地調査時の写真. 上図のB1 B2は対応 する写真の撮影位置 


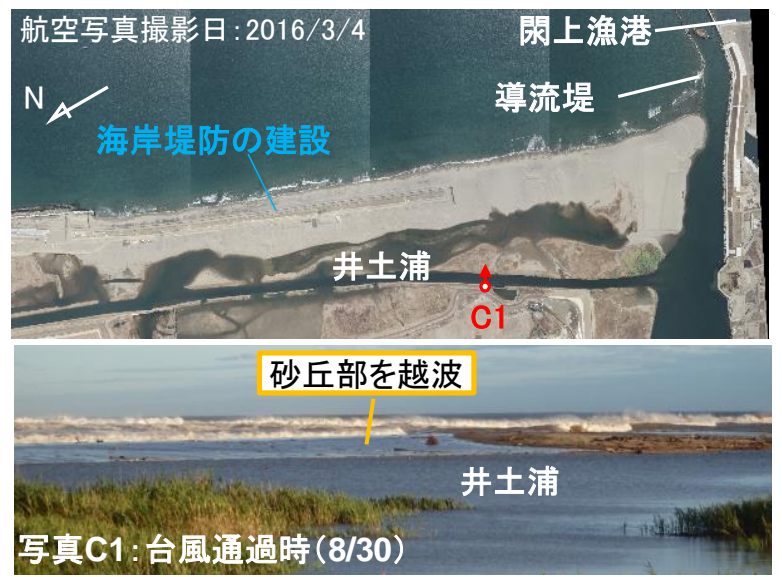

図-4 名取川河口左岸側における現地調査時の写真. 上図のC1 は下の写真の撮影位置

名取川河口周辺部においては明確な水位痕跡が見られな かったが，名取川の河口付近の水位観測所（䦥上第二観 測所）において最大で T.P. $2.05 \mathrm{~m}$ の水位が観測されてい る. 上述の他の水位痕跡を含め, 今回確認された水位痕 跡は 2011 年津波前の海岸堤防の高さである T.P. $5.2 \mathrm{~m}$ よ りも低く, 以前の堤防高さで十分防護可能なレベルの高 潮および高波浪であったといえる.

\section{(2) 地形変化の様子}

対象領域北端部の仙台新港周辺においては 2011 年津 波以降海岸侵食が進み, 盛り土の法先が徐々に侵食され ていた. 盛り土の背後にはすぐにコンテナヤードや道路 があり，また一部は盛り土の上が駐車場となっている.

これらの被災が危惧されることから侵食対策としてこれ まで数度にわたり盛り土法先にサンドバック等が設置さ れており，また北端部から護岸工事が開始されていた(図 -5: A5・A6)，上述のように今次台風では高波浪が盛り土 法先に達しており, これにより, さらに大きく侵食が進 んでいる様子が確認された（写真 $\mathrm{A} 5^{\prime} \cdot \mathrm{A} 6^{\prime}$ )。 また護岸 工事箇所の前面の鋼矢板を越波し, 工事箇所においても 侵食が生じている様子が確認された。蒲生干潟前面の砂 丘部においては越波が生じていたが，台風通過翌日に砂 丘の干潟側において干潟側に倒伏した植物が観察された (写真 A7)。これらの植物は倒伏した状態で根元が埋没 しており，このことは越波による土砂輸送により干潟側 に堆積が生じていたことを示している.

\section{4. 空中写真解析結果}

\section{（1） 七北田川河口から仙台新港}

図-6 は七北田川河口から仙台新港までの空中写真お よび抽出した汀線位置を示している。 なお汀線位置は撮 影時刻および平均的な海浜勾配（0.11）によって潮位補
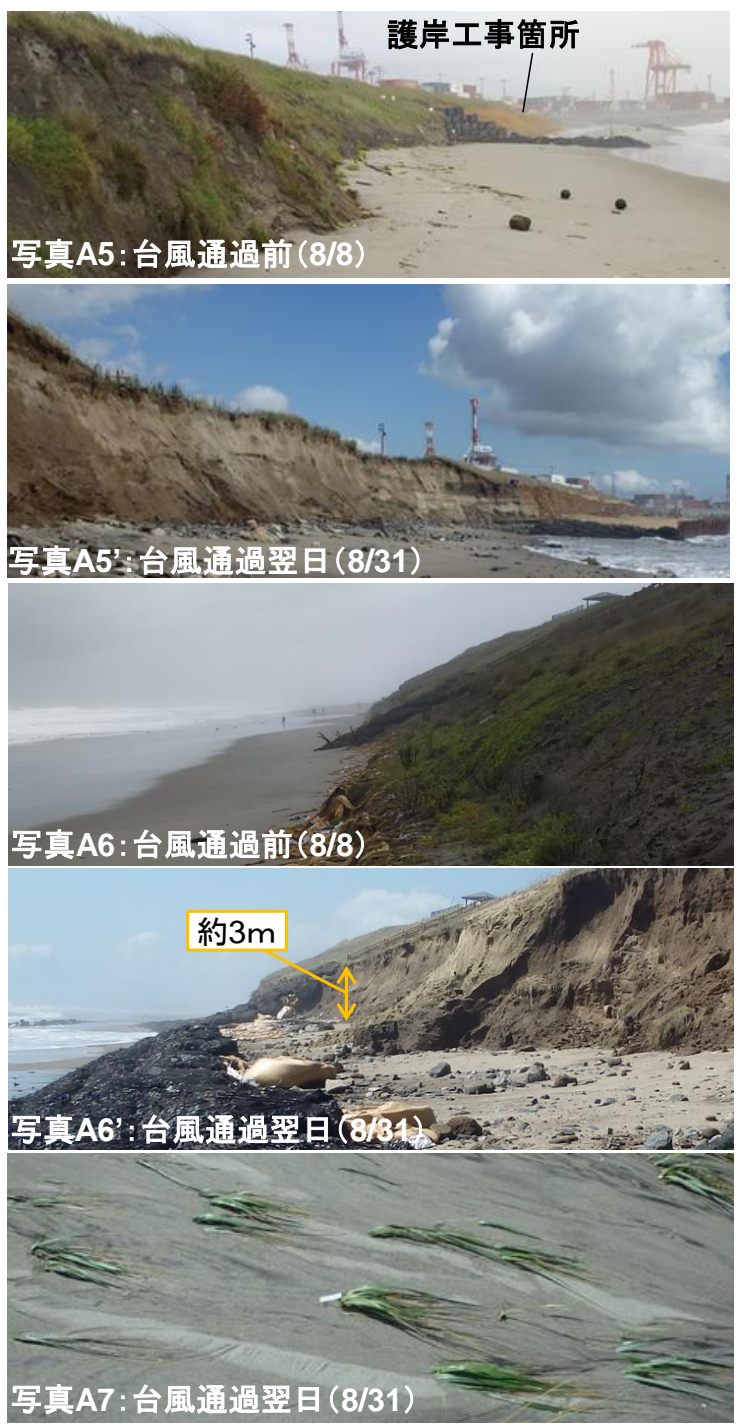

図-5 七北田川河口から仙台新港周辺で確認された地形変化の 様子. 写真の概ねの撮影位置は図-2参照

正した值を示している．空中写真から，全体的に汀線が 後退し, 北端部の盛り土周辺では砂浜が一時的に消失し ていることがわかる。 また，七北田川河口の右岸側から 張り出している河口砂州が大きく削られている. 河口左 岸側においても局所的に侵食が大きく, 左岸導流堤を越 える流れが生じていたことを示唆している．汀線位置を 比較すると, 全体的に約 $30 \mathrm{~m}$ 程度の後退が生じているが その後徐々に回復傾向にある. 特に河口右岸側において は汀線の回復傾向が大きく, 台風来襲から 2 か月後の 11 月 5 日には台風来襲以前よりも汀線が前進している. 本 海岸においては北向きの沿岸漂砂が卓越するが，これが 河口部においてさえぎられることで漂砂上手側の右岸側 において堆積傾向が大きいものと考えられる.

図-7 は2011 年津波来襲直前の 2011 年 3 月 6 日からの 汀線変化を示している. この範囲では津波による蒲生干 潟周辺の大規模な侵食およびその回復に伴う周辺海浜の 侵食 ${ }^{3)}$ により, 一時的に数十〜数百 $\mathrm{m}$ 汀線が後退してい た. その後徐々に汀線位置に回復が見られるものの, 近 

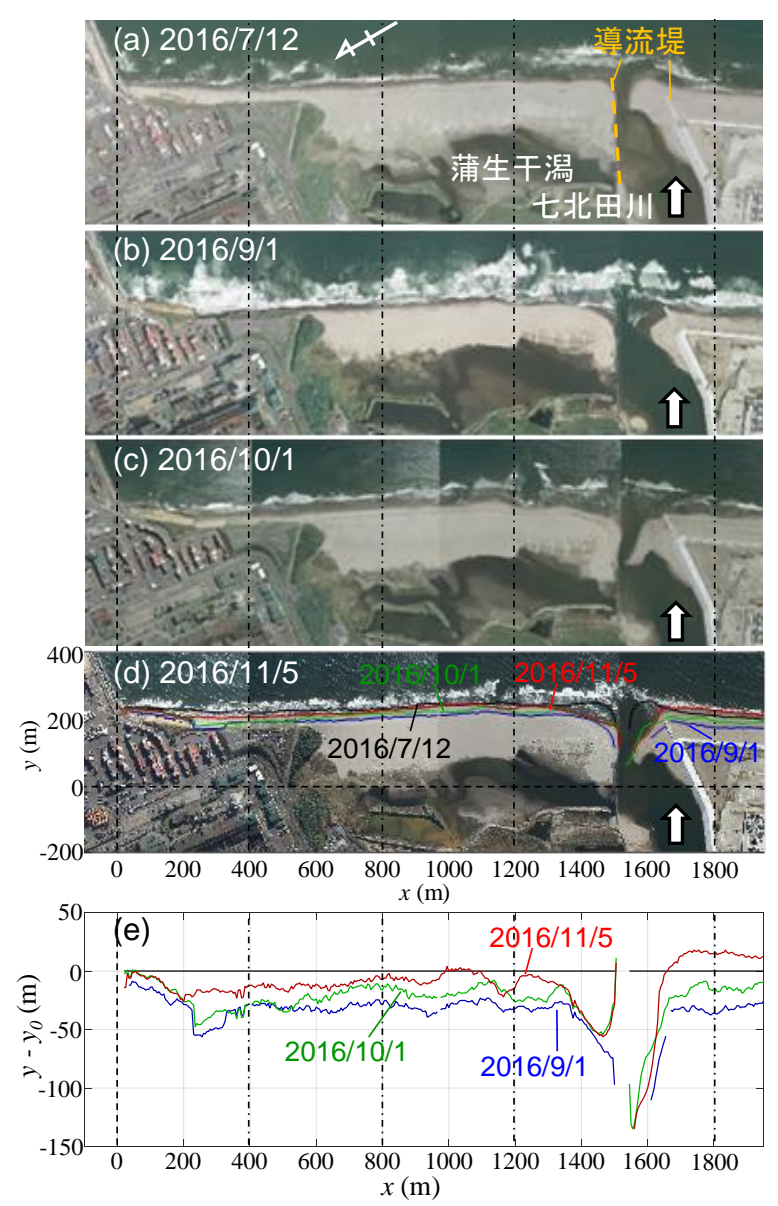

図-6 七北田川河口から仙台新港の空中写真(a) (d) と台風前

(2016/7/12) の汀線位置 $\left(y_{0}\right)$ からの変化量(e)

年の七北田川河口から仙台新港までの汀線位置は津波来 襲直前と比較して数十 $\mathrm{m}$ 下がった位置で遷移していた. 今次台風（2016 年 8 月 30 日）による汀線の後退量は津 波後の汀線変化の中で特筆して大きなものとはならなか ったが，一方で上述のように盛り土部の法先に大きな侵 食が確認されており, 津波により生じた汀線後退が残存 することで仙台新港周辺部における海岸侵食問題を深刻 化させている.

なお，現地調査結果から越波による蒲生干潟内一の土 砂輸送の痕跡が確認されているが，空中写真解析から抽 出した水際線の位置には大きな変化が見られなかった

(図-8). 今次台風による干潟環境への影響を議論するに は地盤高の変化を含めたより詳細な調査が必要である.

\section{(2) 荒浜海岸}

荒浜海岸においては全体的に約 $20 \mathrm{~m}$ 程度の汀線後退 が生じている (図-9). また離岸堤背後に発達していたト ンボロ状の汀線形状が侵食によりやや平坦となっている. 台風来襲 1 か月後にはほぼ台風来襲以前の汀線位置まで 回復している.

この範囲では 2011 年津波後の汀線変化の中で比較的 大きな侵食が生じたが，その後急速に汀線が回復してい

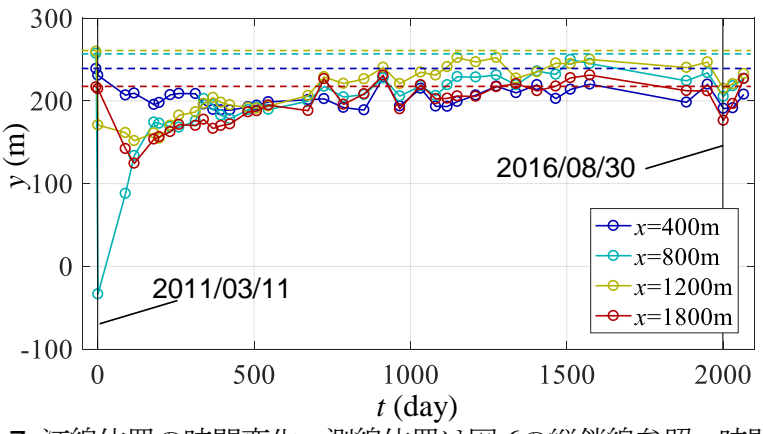

図-7 汀線位置の時間変化. 測線位置は図-6の縦鎖線参照. 時間 は2011年津波来襲 $(2011 / 3 / 11)$ からの日数

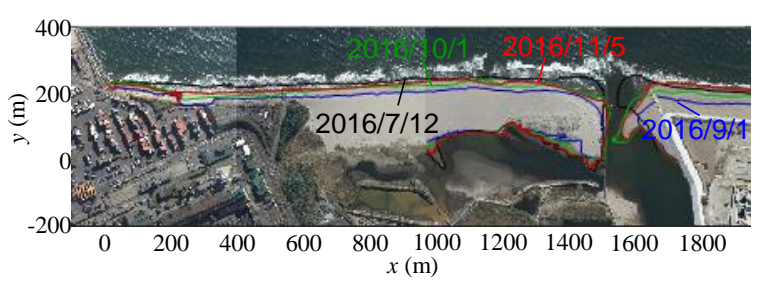

図-8 蒲生干潟周辺の水際線（潮位補正なし）の変化

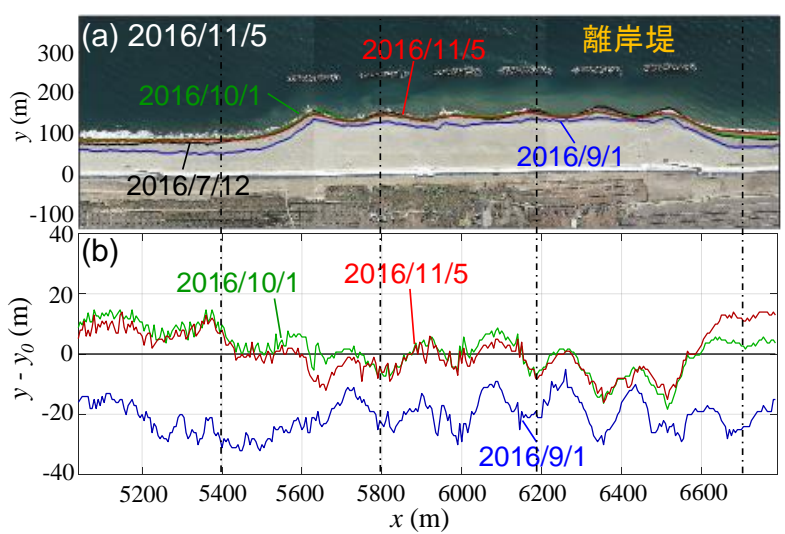

図-9 荒浜海岸の空中写真(a)と台風前（2016/7/12）の汀線位置 ( $\left.y_{0}\right)$ からの変化量(b)

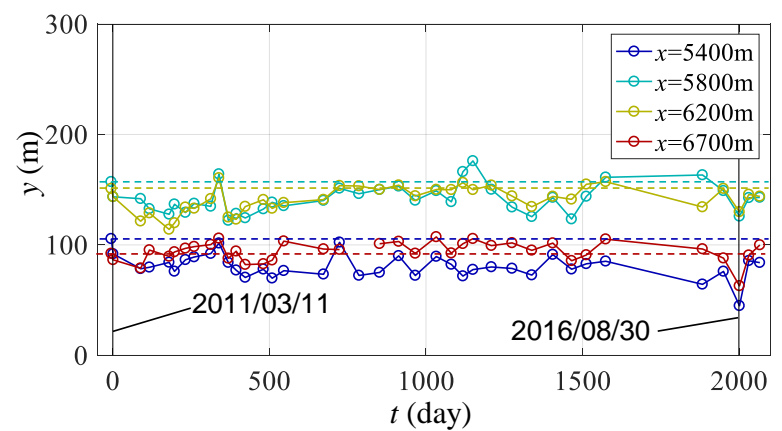

図-10 汀線位置の時間変化. 測線位置は図-9の縦鎖線参照. 時 間は2011年津波来襲 $(2011 / 3 / 11)$ からの日数

る（図-10）．今次イベントによる長期的な影響はないも のと推察される.

\section{(3) 名取川河口から井戸浦周辺}

名取川河口左岸側の井戸浦周辺においても概ね一様 に $20 \mathrm{~m}$ 程度の汀線後退が生じた (図-11).2011 年津波時 には河口砂州の侵食により, 砂州先端部と左岸導流堤の 間に隙間が生じ，その後数年間にわたりこれが維持され 
た．今次イベントにおいても河口砂州先端部の侵食が生 じているが, 河口左岸の導流堤との間に隙間は生じず, 1 か月後の 10 月 1 日においてすでに台風来襲以前よりも砂 州先端に伸長が夕られる. 台風時の洪水流が河口砂州を 越流したことが確認されており，河道側から汀線側へ輸 送された砂が堆積寸ることで河口砂州が海側へ前進した ものと考えられる. また，井戸浦北端部周辺 $(9400<x<$ 9700m）においても汀線の回復が早いが，その他の範囲 ではほとんど汀線の回復がみられない.

井戸浦周辺では 2011 年津波により数百 $\mathrm{m}$ の汀線後退 が生じており，その後徐々に回復が見られるものの，そ の速度は遅く津波以前の汀線から数十 $\mathrm{m}$ 以上後退した ままである (図-12).この領域の北側 $(8000<x<9400 \mathrm{~m})$ では，津波およびその後の侵食により，津波以前は汀線 より陸側に位置していた消波ブロックや直立壁が海岸線 に露出しており，これにより漂砂系の不連続を生じてい る．そのため井戸浦の北端部周辺では北向きの沿岸漂砂 が遮断され堆積傾向が生じている. 2011 年津波による地
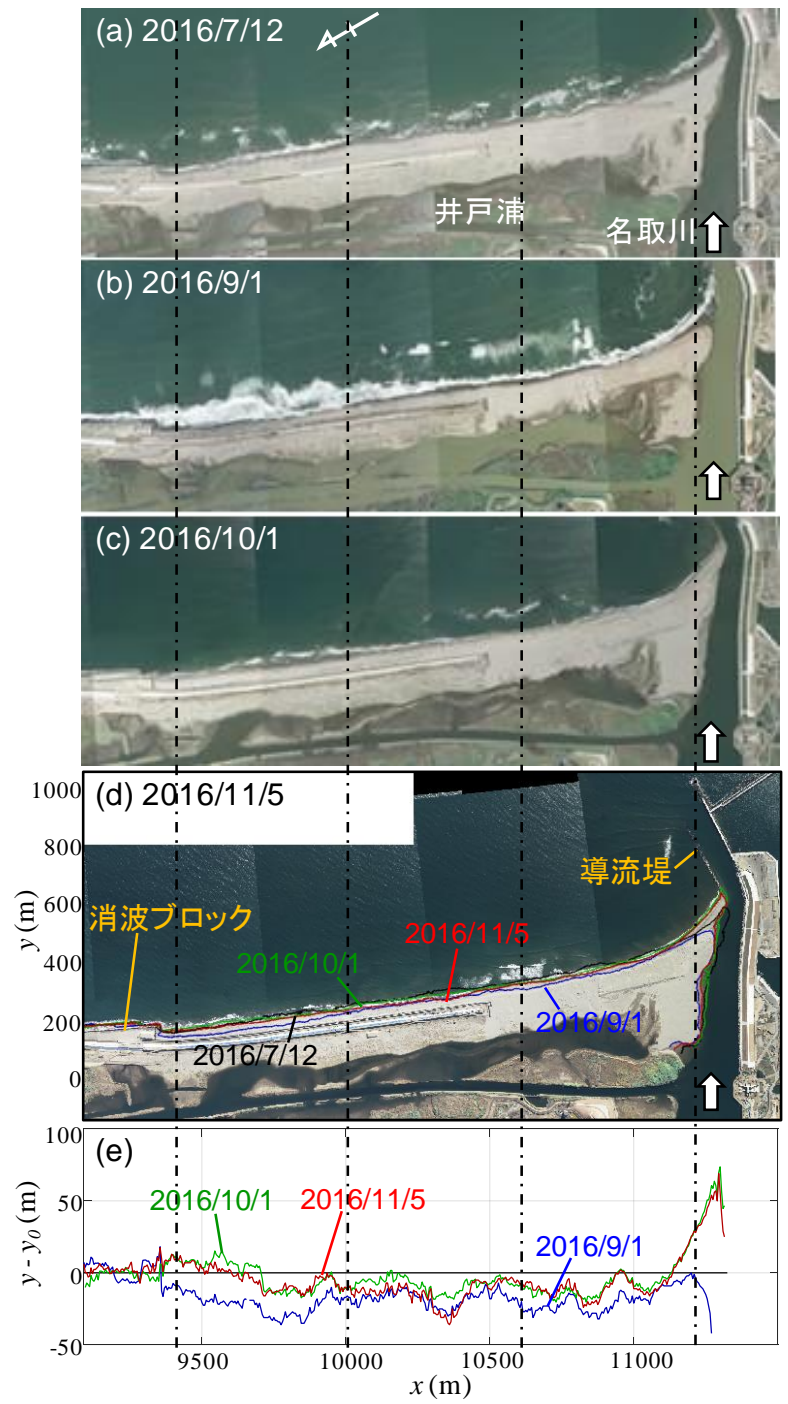

図-11 名取川河口左岸側の空中写真(a) (d) と台風前 (2016/7/12) の汀線位置 $\left(y_{0}\right)$ からの変化量(e)
形変化やそれ以後の汀線変化に対し今次イベントによる 汀線変化は小さい. なお, 海岸堤防建設箇所 $(x<10500 \mathrm{~m})$ とまだ建設が開始されていない領域 $(x>10500 \mathrm{~m})$ にお いて汀線変化に大きな差異は見られなかった。

\section{(4) 対象領域全体}

対象領域全体の汀線変化をみると（図-13），2011 年津 波による侵食およびその後の海浜変形過程において砂浜 の消失した範囲 $(8000<x<9400 \mathrm{~m})$ を除いて概ね一様に 20 30m 程度の汀線後退が生じていることがわかる．構 造物や河口などから離れた領域 $(3000<x<5000 \mathrm{~m})$ では, その後沿岸方向に一様に汀線の回復が生じており，これ は岸沖漂砂による汀線回復が支配的であることを示して いる. 一方で，七北田川河口右岸側や荒浜海岸の離岸堤 群の北側，井戸浦北側に位置する消波ブロック群の北側 といった沿岸漂砂上手側において汀線の前進傾向が強く, 河口や構造物による沿岸漂砂の捕捉効果 ${ }^{4) 5}$ )が寄与して いる. なお，井戸浦北端部の消波ブロック群と同様に， 南蒲生浄化センターの排水路（図-13 参照）についても 津波による汀線後退によりその先端が海岸線に露出され た状態となっているが，その漂砂上手側においても堆積 傾向が大きいことがわかる.

一方で，蒲生干潟や井戸浦の前面においては汀線の回 復が小さい. これらの領域では砂丘を越波したことが確 認されており，また蒲生干潟周辺では前述のように砂丘 の干潟側で砂の堆積が確認されている。 干潟側への越波 による砂の輸送により海浜部から砂が損失していること が岸沖漂砂による汀線回復量の減少に寄与している可能 性がある，今後，今次台風下における越波による干潟側 への土砂輸送量についてより定量的な解析が必要である。

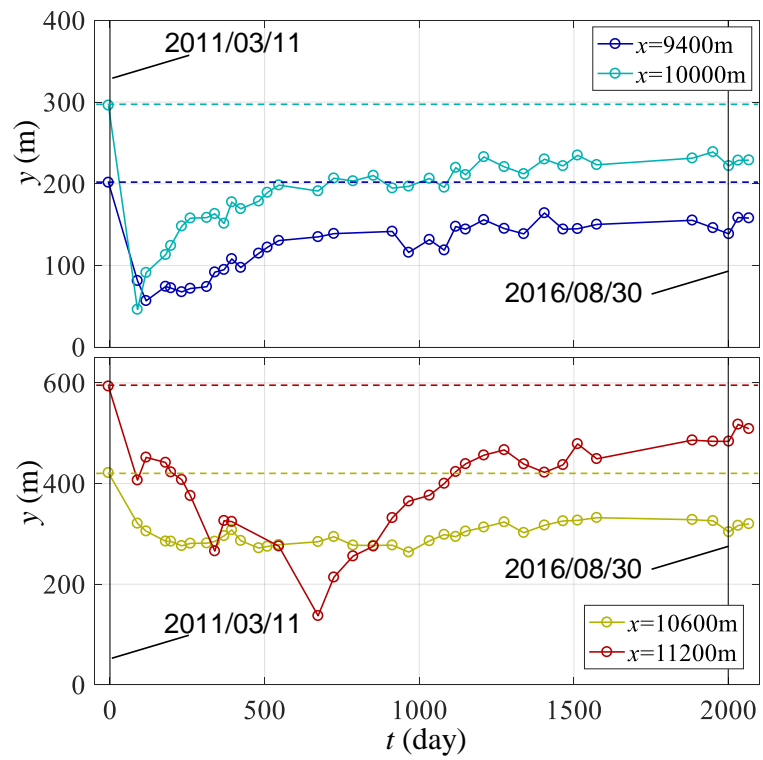

図-12 汀線位置の時間変化. 測線位置は図-11の縦鎖線参照. 時 間は2011年津波来襲 $(2011 / 3 / 11)$ からの日数 


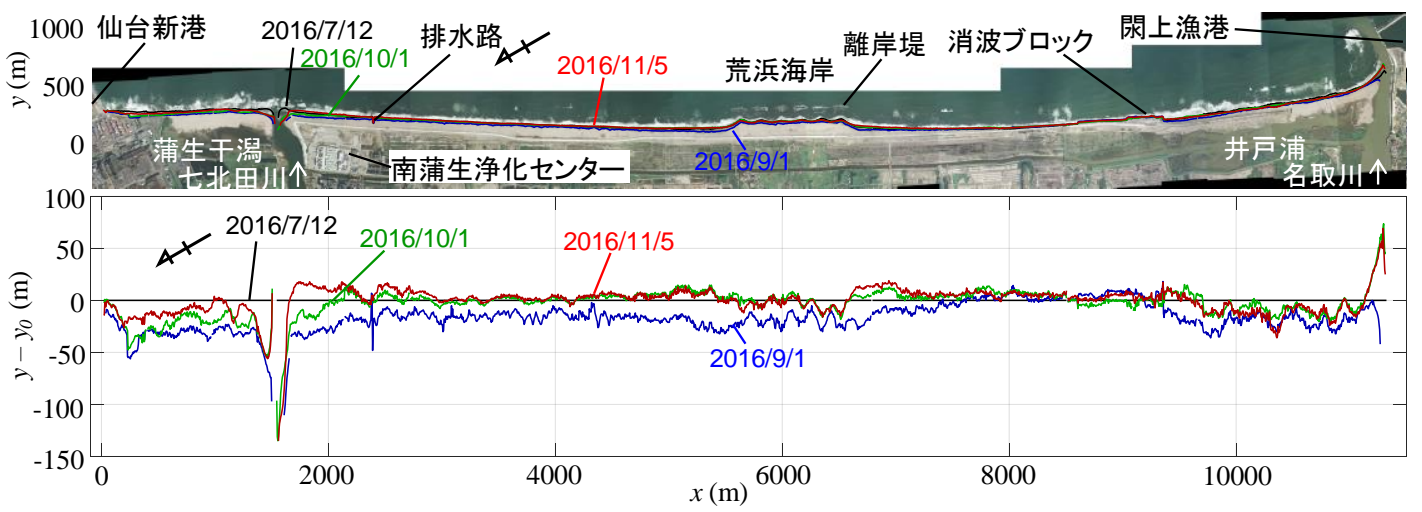

図-13 対象領域全体の空中写真（上）と台風前（2016/7/12）の汀線位置（yo）からの変化量（下）

\section{5. まとめ}

\section{台風通過時の状況及び翌日の痕跡調査から，波浪の遡} 上高が最大で T.P. $4 \mathrm{~m}$ 程度まで達していたことが分かっ た.これは2011 年津波来襲以前の海岸堤防の天端高より も低く，従前の施設により十分防護可能なレベルの高 潮・高波であったと考えられる．また，2011 年津波後に 汀線が後退していた仙台海岸北端部において，高波浪が 海岸沿いの盛り土の法先に達して大きな侵食が生じてい た. その南側の蒲生干潟や名取川河口左岸側の井戸浦に おいてはその前面の砂丘部において越波が生じており, これにより干潟内部への土砂輸送が生じた。

汀線解析から本領域で全体に 20 30m 程度の汀線後退 が生じたことが分かった. その後岸沖漂砂の寄与により， 急速な汀線の回復が生じているが，蒲生干潟や井戸浦周 辺での汀線回復はほかの領域と比較して遅く, 越波によ る土砂輸送量についてより詳細な検討が必要であろう. また, 河口や離岸堤の他に 2011 年津波による侵食によっ て海岸線に露出した構造物によって沿岸漂砂が遮断され ており, 漂砂系の不連続が生じていることが確認された.
謝辞 : 本研究に対して河川財団河川整備基金の助成を受 けた。また本稿で示した仙台新港における波浪観測值は 国土交通省港湾局が観測し港湾空港技術研究所で処理さ れた速報值である。ここに記して謝意を表する。

\section{参考文献}

1) 内閣府: 平成 28 年台風 10 号による被害状況等につい て, http://www.bousai.go.jp/updates/h28typhoon10/, 2016.

2) Vo Cong Hoang, 田中 仁, 三戸部佑太 : 東日本大震 災津波後の仙台海岸広域漂砂系の回復状況，土木学会 論文集 B2 (海岸工学), Vol.72, No.2, pp.I_769-I_774, 2016.

3） Vo Cong Hoang, 田中 仁，三戸部佑太 : 津波により 侵食された河口部の sink 効果による周辺海浜での汀 線後退, 土木学会論文集 B2 (海岸工学), Vol.70, No.2, pp.I_506-I_510, 2014.

4) 姜 炫宇，田中 仁，坂上 毅：長期現地観測資料に 基づく仙台海岸汀線変動特性・土砂収支の検討, 海岸 工学論文集, Vol.51, pp. 536-540, 2004.

5) Eko Pradjoko, 田中 仁 : 沿岸漂砂系に流入する河口 左右岸の汀線変動特性に関寸る研究，土木学会論文集 B2 (海岸工学), Vol. 66, No. 1, pp.541-545, 2012.

(2017.2.2 受付)

\section{MORPHOLOGICAL CHANGE ON SENDAI COAST BY TYPHOON NO.10, 2016}

\section{Yuta MITOBE, Hitoshi TANAKA, Akihiro SUZUKI, Makoto UMEDA, Daisuke KOMORI and Yoshiya TOUGE}

Impact of high tide and high waves due to typhoon No.10, 2016 was discussed through field surveys under and after the typhoon event. From visual observation and debris carried in the event, maximum run-up height on Sendai Coast was estimated to be about T.P. 4 m. Severe erosion of embankment toe along the coast line near Sendai Port was observed. Due to overtopping of high waves over sand dune, some amount of sediment was transported into Gamo Lagoon.

$20 \sim 30 \mathrm{~m}$ retreat of shoreline was observed through shoreline analysis based on aerial photographs taken before and after the typhoon. In one or two months after the event, shoreline positions almost reached to the positions before the typhoon mainly due to the contribution of the cross-shore sediment transport. However, the recovery was relatively slow in the area around Gamo Lagoon and Idoura Lagoon where the wave overtopping over the sand dunes were observed during the field survey. In addition to a river mouth and detached breakwaters, some structures revealed to coast line due to the erosion by the 2011 tsunami have effect to block the longshore sediment transport to induce faster recovery of the shoreline on the up-drift side of the longshore sediment transport. 